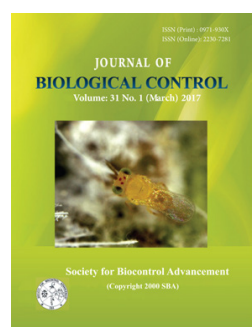

\title{
Effect of IPM modules on population of natural enemies on Soybean
}

\author{
A. A. MOTAPHALE ${ }^{*}$, B. B. BHOSLE and F. S. KHAN \\ Department of Agricultural Entomology, Vasantrao Naik Marathwada Krishi Vidyapeeth, Parbhani - 431 402, Maharashtra, India \\ ${ }^{*}$ Corresponding author E-mail: dr.ashvini24@gmail.com
}

\begin{abstract}
Field experiments were conducted during kharif 2010-2011 and 2011-12, in the field of Department of Agricultural Entomology, College of Agriculture, Marathwada Krishi Vidyapeeth, Parbhani (Maharashtra). During this experiment, significantly highest population (1.70 LB/5 plants) of lady bird beetle, ( 1.00 chrysopa $/ 5$ plants) of chrysopa and ( 1.60 spiders $/ 5$ plants $)$ of spider were observed in untreated control and were at par with MAU IPM module. Significantly lowest population was observed in chemical control treatments.
\end{abstract}

KEY WORDS: Chrysopa, Integrated pest management, IPM, Lady bird beetle, Natural enemies, Spider

(Article chronicle: Received: 12.02.2017; Revised: 28.03.2017; Accepted: 31.03.2017)

\section{INTRODUCTION}

Soybean (Glycine max (L.) Merill) grows well in varied agro-climatic conditions and emerged as important commercial crops in many countries and international trade of soybean is spread globally. The use of broad-spectrum insecticides is one of the main obstacles to effective biological control because natural enemies are just as susceptible to the insecticide as the pest. Different pesticides have been used for control of Soybean pests. But several pesticides have broad spectrum activity and are highly toxic to nontarget organisms. Among many predators on soybean like lady bird beetle (Coccinella septempunctata), chrysopa (Chrysoperla arabica) and spider are predominant. Most species of ladybirds are considered beneficial because they are predators of Homoptera or Acarina, many of which are considered to be pests. A single lady beetle may eat as many as 5,000 aphids in its lifetime. Releases of C. carnea eggs in field cages at rates of 50,000 and 100,000 per acre also provided effective control of the tobacco budworm. Therefore present field studies were undertaken to determine the integrated pest management modules on population of lady bird beetle, chrysopa and spider on soybean.

\section{MATERIAL AND METHODS}

During IPM experimental design MAUS 7 variety sown by spacing 45 x $5 \mathrm{~cm}$ under Randomized Block Design (RBD) of plot size $9.9 \times 9.0 \mathrm{~m}$ in which 3 treatments with 7 no. of replications were taken. Distance between two replications and plots were $2 \mathrm{~m}$ and $1 \mathrm{~m}$ respectively. Components of IPM modules are given in Table 1. Population of Lady bird beetle, Chrysopa and spider were recorded on randomly selected five plants from each net plot on weekly interval during both the years.

Statistical analysis: As per Gomez and Gomez (1984), the data obtained on live population i.e. observations on larval population were subjected to $\sqrt{ } \mathrm{X}+0.5$ transformation i.e. Poisson formula. Whereas data on per cent infestation were transformed into arc sin transformation values before statistical analysis.

$$
\mathrm{X}=\text { average number of pest population. }
$$

\section{RESULT AND DISCUSSION}

\section{Effect of different IPM modules on population of Lady bird beetle}

The data presented in Table 2 revealed that during $k h a$ rif 2010-11, untreated control recorded highest population of (1.55 LB/5 plants) of lady beetle which was at par with MAU IPM module ( $0.80 \mathrm{LB} / 5$ plants). Significantly lowest population of $(0.60 \mathrm{LB} / 5$ plants $)$ was observed in chemical control treatment .As during kharif 2011-12, untreated control recorded significantly highest population of (1.85 LB/5 plants) of lady beetle followed by MAU IPM module ( $0.85 \mathrm{LB} / 5$ plants) which were found at par with each other. Significantly lowest population of $(0.70 \mathrm{LB} / 5$ plants $)$ was 
Table 1. Components of different IPM modules

\begin{tabular}{|c|c|c|c|}
\hline \multirow[t]{2}{*}{ Module } & \multirow[t]{2}{*}{ Components used } & \multicolumn{2}{|c|}{ Date of applications } \\
\hline & & $2010-2011$ & 2011-12 \\
\hline \multirow{11}{*}{$\begin{array}{l}\text { 1.MAU } \\
\text { Module }\end{array}$} & 1. Deep summer ploughing before soybean cultivation. & $17-06-2010$ & $11-07-2011$ \\
\hline & 2. Border row of trap crops i.e. castor and sunflower & 09-07-2010 & 25-07-2011 \\
\hline & * Recommended spray adopted on trap crop after noticing incidence & $\begin{array}{l}25-08-2010 \\
20-09-2010\end{array}$ & $\begin{array}{l}16-09-2011 \\
28-09-2011\end{array}$ \\
\hline & 3. Destruction of alternative hosts & Done & Done \\
\hline & 4. Installation of $25 \mathrm{bird}$ perches $/ \mathrm{ha}$ & $30-6-2010$ & 21-07-2011 \\
\hline & $\begin{array}{l}\text { 5. Mechanical collection and destruction of stemfly and girdle beetle af- } \\
\text { fected plant parts }\end{array}$ & Done & Done \\
\hline & 6. Application of phorate $10 \mathrm{G} @ 10 \mathrm{Kg} / \mathrm{ha}$ in soil before sowing & $17-06-2010$ & $11-07-2011$ \\
\hline & 7. Spraying of NSKE $5 \%$ at $25-30$ days after sowing & 13-07-2010 & 06-08-2011 \\
\hline & $\begin{array}{l}\text { 8. Collection and destruction of Spodoptera egg masses and gregarious } \\
\text { larvae along with leaves. }\end{array}$ & Done & Done \\
\hline & 9. Nomuraea rileyi@4 g/l after noticing incidence of Spodoptera litura & $17-07-2010$ & $12-08-2011$ \\
\hline & 10. Use of chemical insecticides after crossing the ETL. & $\begin{array}{l}16-08-2010 \\
04-09-2010 \\
\end{array}$ & $\begin{array}{l}17-09-2011 \\
01-10-2010\end{array}$ \\
\hline \multirow{4}{*}{$\begin{array}{l}\text { 2.Chemical } \\
\text { Control }\end{array}$} & 1. Triazophos40 EC @ 0.064\% & 03-07-2010 & 26-07-2011 \\
\hline & 2. Quinalphos 25EC@0.05\% & $17-07-2010$ & $10-08-2011$ \\
\hline & 3. Emamectin benzoate 5SG @ 0.002\% & $05-08-2010$ & 25-08-2011 \\
\hline & 4. Indoxacarb 14.5\%@0.0145\% & $18-08-2010$ & $10-09-2011$ \\
\hline $\begin{array}{l}\text { 3. Untreated } \\
\text { control }\end{array}$ & $\begin{array}{l}\text { No plant protection measure adopted. } \\
\text { The plots were sprayed with plain water. }\end{array}$ & & \\
\hline
\end{tabular}

observed in chemical control treatment. Results based on pooled data revealed that untreated control recorded significantly highest population of (1.70 LB/5 plants) of lady beetle and was at par with MAU IPM module $(0.82 \mathrm{LB} / 5$ plants). Significantly lowest population was observed in chemical control treatment $(0.65 \mathrm{LB} / 5$ plants). Results obtained during present experiment are in conformity with the findings of Patil and pawar (1994) who observed highest population of natural enemies in control followed by NPV (a) 500 and 250 LE/ha. Patil et al. (2008) reported highest predatory activities in untreated control $(0.44 /$ plant $)$ followed by imidacloprid 70 WS @ 4.9 g a.i./kg (0.38/plant) and thiamethoxam $3 \mathrm{~g}$ a.i. $/ \mathrm{kg}(0.35 /$ plant $)$ at 15 and 25 DAS during 2005-06. Rathod (2011) reported that highest population of coccinellids in untreated control which was at par with BIPM module, MAU module. Significantly lowest population was observed in chemical control treatment.

\section{Effect of different IPM modules on population of Chrys- operla arabica}

The data presented in Table 3 revealed that during kharif 2010-11, untreated control recorded highest population of (1.00 chrysopa /5 plants) of Chrysoperla arabica followed by MAU IPM module ( 0.65 chrysopa $/ 5$ plants)) which were found at par with each other. Significantly lowest population of ( 0.55 chrysopa / 5 plants) was observed in chemical control treatment. During kharif 2011-12, untreated control recorded significantly highest population of (1.10 chrysopa /5 plants) of Chrysoperla arabica followed by MAU IPM module ( 0.70 chrysopa $/ 5$ plants) which were found at par with each other. Significantly lowest population was observed in chemical control treatment $(0.60$ chrysopa

Table 2. Effect of IPM modules on population of lady beetle, Chrysopa and spiders

\begin{tabular}{|l|l|c|c|c|c|c|c|c|c|c|}
\hline \multirow{2}{*}{ Sr.no. } & \multirow{2}{*}{ Modules } & \multicolumn{3}{|c|}{ No. of LB per 5 plants } & \multicolumn{3}{c|}{ No. of Chrysopa per 5 plants } & \multicolumn{3}{|c|}{ No. of spiders per 5 plants } \\
\cline { 3 - 11 } & & $2010-11$ & $2011-12$ & Pooled & $2010-11$ & $2011-12$ & Pooled & $2010-11$ & $2011-12$ & Pooled \\
\hline \multirow{2}{*}{1.} & MAU IPM & 0.80 & 0.85 & 0.82 & 0.65 & 0.70 & 0.68 & 1.20 & 1.30 & 1.25 \\
& Module & $(1.57)$ & $(1.73)$ & $(1.65)$ & $(1.00)$ & $(1.20)$ & $(1.25)$ & $(1.41)$ & $(1.48)$ & $(1.45)$ \\
\hline 2. & Chemical & 0.60 & 0.70 & 0.65 & 0.55 & 0.60 & 0.57 & 0.70 & 0.80 & 0.75 \\
& control & $(1.21)$ & $(1.24)$ & $(1.25)$ & $(1.11)$ & $(1.14)$ & $(1.13)$ & $(1.04)$ & $(1.12)$ & $(1.00)$ \\
\hline 3. & Untreated & 1.55 & 1.85 & 1.70 & 1.00 & 1.10 & 1.05 & 1.60 & 1.40 & 1.50 \\
& control & $(1.81)$ & $(2.00)$ & $(1.45)$ & $(1.21)$ & $(1.35)$ & $(1.45)$ & $(1.80)$ & $(1.83)$ & $(1.74)$ \\
\hline SE \pm & 0.11 & 0.10 & 0.09 & 0.10 & 0.08 & 0.09 & 0.08 & 0.07 & 0.11 \\
\hline \multicolumn{2}{l|l}{ CD at 5\% } & 0.31 & 0.30 & 0.28 & 0.31 & 0.33 & 0.28 & 0.26 & 0.23 & 0.35 \\
\hline
\end{tabular}

Figures in parentheses are $\sqrt{x+0.5}$ transformed values ${ }^{\star}$ Average of 8 weeks 
/ 5 plants). Pooled data revealed that untreated control recorded highest population of (1.05 chrysopa /5 plants) of Chrysoperla arabica followed by MAU IPM module (0.68 chrysopa $/ 5$ plants) which were found at par with each other. On the contrary significantly lowest population of $(0.57$ chrysopa / 5 plants) was observed in chemical control treatment. Results obtained during present investigation are in conformity with the findings of Rajaram et al. (2001) who reported 1 and 8 population per plant was in IPM module and 0.7 and 2 in farmers method with 6 sprays of insecticides during consecutive season, respectively. Sarode and Sonalkar (1999) tested the insecticidal products for their biosafety to Chrysoperla zotswani arabica under laboratory condition. None of the insecticides was found safer predators. However Neem seed Kernen extract proved comparatively safe. Bhosle et al. (2009) observed that the mean population of chrysopa was 1.04 per plant in IPM and in non-IPM module it was 0.61 per plant.

Table 3. Effect of IPM modules on population of Chrysoperla arabica

\begin{tabular}{|l|l|l|l|l|}
\hline \multirow{2}{*}{ Sr. No. } & \multirow{2}{*}{ Modules } & \multicolumn{3}{|c|}{ No. of Chrysopa per 5 plants } \\
\cline { 3 - 5 } & & $2010-11$ & $2011-12$ & Pooled \\
\hline 1 & MAU IPM module & $0.65^{*}$ & 0.70 & 0.68 \\
\hline & & $(1.00)$ & $(1.20)$ & $(1.25)$ \\
\hline 2 & Chemical control & 0.55 & 0.60 & 0.57 \\
\hline & & $(1.11)$ & $(1.14)$ & $(1.13)$ \\
\hline 3 & Untreated control & 1.00 & 1.10 & 1.05 \\
\hline & & $(1.21)$ & $(1.35)$ & $(1.45)$ \\
\hline & SE \pm & 0.10 & 0.08 & 0.09 \\
\hline & CD at 5\% & 0.31 & 0.33 & 0.28 \\
\hline
\end{tabular}

Figures in parentheses are $\sqrt{x+0.5}$ transformed values

\section{Effect of different IPM modules on population of spi- ders}

During kharif 2010-11 presented in Table 4, untreated control recorded highest population of (1.60 spiders $/ 5$ plants) followed by (1.20 spiders $/ 5$ plants) in MAU IPM module. Significantly lowest population of $(0.70$ spiders $/ 5$ plants) was observed in chemical control treatment. Whereas during kharif 2011-12, untreated control recorded highest population of (1.40 spiders $/ 5$ plants) spiders followed by MAU IPM module ( 1.30 spiders/5 plants). Significantly lowest population of ( 0.80 spiders / 5 plants $)$ was observed in chemical control treatment. Results based on the pooled data revealed that untreated control recorded highest population of (1.50 spiders $/ 5$ plants) which was at par with MAU IPM module (1.25 spiders /5 plants). On the contrary significantly lowest population of ( 0.75 spiders / 5 plants $)$ was observed in chemical control. Results obtained during present investigation are in conformity with those of Ameta et al. (2004) who observed that IPM module supported higher population owing to non chemical formulations. Similarly Dhawan et al. (2009) observed higher population of natural enemies in IPM as compared to non IPM. Bhute
(2010) recorded (1.11 spiders/plants) in untreated control which was significantly superior over all other modules and at par with BIPM module (0.93 spiders/ plant).

Table 4. Effect of IPM modules on the population of spiders

\begin{tabular}{|l|l|l|l|l|}
\hline \multirow{2}{*}{ Sr. No. } & \multirow{2}{*}{ Modules } & \multicolumn{3}{|c|}{ No. of spiders per 5 plants } \\
\cline { 3 - 5 } & & $2010-11$ & $2011-12$ & Pooled \\
\hline 1 & MAU IPM module & $1.20^{*}$ & 1.30 & 1.25 \\
\hline & & $(1.41)$ & $(1.48)$ & $(1.45)$ \\
\hline 2 & Chemical control & 0.70 & 0.80 & 0.75 \\
\hline & & $(1.04)$ & $(1.12)$ & $(1.00)$ \\
\hline 3 & Untreated control & 1.60 & 1.40 & 1.50 \\
\hline & & $(1.80)$ & $(1.83)$ & $(1.74)$ \\
\hline & SE \pm & 0.08 & 0.07 & 0.11 \\
\hline & CD at 5\% & 0.26 & 0.23 & 0.35 \\
\hline
\end{tabular}

Figures in parentheses are $\sqrt{x+0.5}$ transformed values

\section{REFERENCES}

Ameta OP, Rana BS, Bombawale OM. 2004. Validation of IPM technology in cotton in southern Rajasthan. Pestology 28(11): 27-30.

Bhute NK. 2010. Pest management in Bt cotton M.Sc. (Agri.) thesis, MAU, Parbhani.

Dhawan AK. 2000. Impact of some new insecticides on natural enemy complex on cotton ecosystem. Pestology 24(5): 8-14.

Gomez KA, Gomez AA. 1984. Statistical procedures for agricultural research. An International rice research Institute Book. Wiley Interscience pub. John Wiley and Sons. New York, U.S.A. pp. 139-153.

Patil SB, Pawar VM. 1994. Bioefficacy and compatibility of methomyl $40 \mathrm{SP}$ alone and in combination with HaNPV against coccinellid predator of cotton. Pestology 18(10): 25-26.

Patil SB, Udikeri SS, Renuka BH, Guruprasad GS, Shaila HM, Abhilash. 2008. New seed dresser thiamethoxam 500 FS - N0 compromise in efficacy against sucking pests. An experimental evidence from cotton. Pestology 32(5): 13-15.

Rajaram V, Ramamurthy R, Krishnadoss D. 2001. Demonstration of Integrated pest management in cotton farmer's field. J Cotton Res Dev. 15(2): 168-170.

Rathod PK. 2011. Evaluation of IPM modules for soybean. Ph.D. (Agri) Thesis, MKV, Parbhani.

Sarode SV, Sonalkar VD. 1999. Ovicidal effect of some insecticides against Chrysoperla carnea. Steph. Pesticide Res J. 11(1): 97-98. 